\title{
ПСИХОАНАЛИТИЧЕСКИЙ ПОДХОД К ЛЕКСИЧЕСКОМУ ЗНАЧЕНИЮ СЛОВА
}

\begin{abstract}
Аннотация. Предметом исследования служит лексический анализ речи человека, а также текста художественного произведения с точки зрения психоаналитического подхода. Автор исходит из открытия бессознательного, сделанного 3. Фрейдом, и выдвигает гипотезу, что если бессознательное определяет большую часть нашей деятельности, то в словах, сказанных или написанных человеком, должны наиболее ярко проявляться бессознательные мотивы и желания. В психолингвистике есть свой категориальный аппарат (индексация ключевых слов, набор ключевых слов (НКС) и др.), который автор статьи предлагает использовать для психоаналитического анализа речи и текста. Бессознательное посредством речи и письма прорывается вопреки цензуре сознательного. Автор приводит примеры нахождения таких бессознательных слов, с помощью которых можно создать психологический портрет человека. По прошествии времени психоанализ установил обширные и глубокие связи с другими методами исследования: методами естественнонаучного наблюдения, соматического осмотра, психологического эксперимента, антропологических полевых исследований и исторических изысканий. Дополнить связи психоанализа может метод лексического анализа речи, текста, пронизывающий всю триаду психоаналитической деятельности: терапевтический контакт, концептуальный проект и систематический самоанализ. Основным выводом проведенного исследования является заключение, что лексический анализ речи, текста может выявлять слова, идущие из глубин бессознательного, и это не только слова-оговорки, по 3. Фрейду, а бессознательно сказанные слова, которые своими смыслами характеризуют истинные мотивы, желания, мысли человека, его действия. Такие бессознательные ключевые слова могут составлять челые фразы об истинных чувствах, желаниях, мотивах человека. Новизна исследования заключается в нахождении (индексации) бессознательных ключевых слов, которые могут характеризовать не только одного человека, но и выявлять психологическое состояние людей определенной культуры.
\end{abstract}

Ключевые слова: лексический анализ, доминанта, психоанализ, бесознательное, вербальное, невербальное, психолингвистика, ключевое слово, оговорка, универсально-предметный код.

Abstract. The subject of the research is the lexical analysis of human speech as well as literary texts from the point of view of the psychoanalytical approach. The author of the article bases his research on the concept of unconcious offered by Freud. The author makes a hypothesis that if the major part of our activity is defined by unconscious elements, then words said or written should be the brightest manifestation of our motives and desires. The author offers to use psycholinguistic categories and concepts (indexation of key words, set of key words and etc.) to carry out a psychoanalytical analysis of speech and texts. Our unconscious speaks itself through speech and creative writing despite critics of our conscious. The author gives examples of such unconscious words that may be used to create a psychological portrait of a person. With time, psychoanalysis has defined wide and deep connections with other research methods such as natural science observation, physical check-up, psychological experiement, anthropological field researches and historical researches. Psychoanalysis cn be also completed with the method of the lexical analysis of speech and texts that are found in all the elements of the psychoanalytical session triad: therapeutical contant, conceptual project and systemic self-analysis. The main conclusion of the research is that the lexical analysis of speech and texts can define words that come from the depth of our unconscious and these are not just slips of the tongue described by freud but also unconsciously said words that characterise one's true motives, desires, thoughts and actions. Such unconscious key words may describe not only one individual but also define psychological states of a certain nation or ethos.

Key words: keyword, psycholinguistics, Non-verbal, Verbal, unconscious, psychoanalysis, dominant, lexical analysis, slip, universal-subject code.

«Образ мира, в слове явленный» (Б. Пастернак)

$\Pi$ ервое слово у ребенка это слово мама. Слово мама означает для маленького создания все сущее, означает жизнь и смерть. Оно появляется внезапно и восприни- мается из контекста всего происходящего. Этому слову может никто не обучать специально, может пытаться проговаривать с ним отдельные слоги, обучать говорить, но у большинства младенцев 
это слово произносится первым. Это ли не тайна творения? Без материнской заботы ребенок может погибнуть, мама дает ему питание, она дала младенцу жизнь. Мама макрокосм младенца. Поэтому он называет ее первым своим словом, определяя главное содержание своей жизни, вызывая, таким образом, восхищение окружающих и, выражая признательность маме за появление на свет и существование. Подсознательно ребенок понимает важность в его жизни именно этого слова. Слово мама это Вселенная младенца. Ребенок обладает словарным составом - лексикой и словарным запасом, заключающимся в одном таком важном и родном слове - мама. Поэтому активный словарный запас ребенка включает одно слово. Пассивный словарь, слова, которые ребенок понимает, но не может произнести включает больше чем одно слово.

Слово можно рассматривать в разных аспектах в зависимости от того, какая из ключевых функций языка и речи представляется наиболее важной. Если данное понятие исследуется через призму функции общения, то с соответствующей точки зрения слово обычно понимается как наименьший значимый элемент потока речи. Если в центре внимания аналитика находится функция обобщения, то слово представляется способом или формой закрепления знаний. С другой точки зрения, В.И. Аннушкин в статье «Язык-речь-слово в духовной литературе» пишет, что «слово действует в качестве своеобразной абстрактной идеи, условного обозначения, которое в разнообразных видах речевой или мыслительной деятельности человека замещает класс предметов или явлений. В этом случае оно представляет собой частный случай знака» ${ }^{[1]}$.

Если представить словарный состав, точнее словарный запас человека в качестве пирамиды, то у младенца эта пирамида плоская, где в основании лежит слово, понятие мама. Это характеризует всю совокупность всех факторов, все миросозерцание ребенка.

Каждый отдельный человек имеет свой индивидуальный активный словарь. Индивидуальный активный словарь различен у всех людей. К примеру, «Словарь языка Пушкина», включающий используемые им слова, содержит более 20 тыс. слов [5]. Но словарный запас А.С. Пушкина никак не может содержать 21192 слов, опубликованных в 4-х томном словаре Пушкина. Словарный запас, который использовал в своих произведениях А.С. Пушкин, в сорок два раза больше. В статье Н. Юшковой сказано: «Во всех, исследуемых текстах Александра Сергеевича, насчитывается 900313 слов» [17], а статье «Словарный запас. Что это?» написано, что «высокообразованный человек имеет в словарном запасе около восьми тысяч слов, а выпускник средней школы около пяти тысяч» ${ }^{11]}$.

В словаре у Эллочки-людоедки из произведения И. Ильфа и Е. Петрова в запасе было 30 слов, но, активный словарный запас состоял из 17 слов, причем ими она могла выразить практически любую свою мысль.

Словарный запас языка у каждого человека, безусловно, есть отражение глубины его внутреннего мира, его интеллектуальных способностей и связано с подсознательной деятельностью человека. Чем больше слов знает и использует индивид, тем более глубокий и сложный его внутренний мир, тем больше человек знает, различает, понимает и может высказать. Можно распознавать лексические конструкции состава языка с целью определить профессиональные предпочтения человека, его увлечения, происхождение, но это не будет иметь большого значения с психоаналитической точки зрения. Для психоаналитической деятельности более подходят глубинные аспекты лексического значения слова и словообразования, такие как оговорка, описка, очитка, ослышка, слова-ловушки, и даже слова отрицания «не», «нет». Все эти слова характеризуют его внутренний мир, неосознанные самим человеком процессы. Мышление человека происходит на знаковом уровне жестов, эмоций, мимики, мысль изначально невербальна. Л.С. Выготский сравнил мысль с облаком проливающимся дождем слов. Н.И. Жинкин выдвинул теорию о невербальном языке интеллекта - универсально-предметном коде (УПК). Именно в УПК происходит первичное появление смысла, которое затем перекодируется с языка предметно-схемного на вербальный язык. В слове происходит второе рождение мысли. Таким образом, мысль невыразима полностью словами, она может быть переведена с языка жестово-изобразительного (ЖИ) на вербальный язык. Для более глубокого понимания неосознаваемых человеческих процессов необходимо изучение развития человеческого общества с самых древних времен, зарождение первых звуков и слов в общении первобытного общества.

\section{Происхождение первых слов}

Древний язык возник в Африке 200 или 400 тысяч лет назад. Древнейшие письменные языки, которые нам известны, скажем древнеегипетский, шумерский, возникли всего лишь 4-3 тысячелетие до нашей эры. Ученые могут реконструировать историю языков чуть глубже, но не больше чем 10-15 тысяч лет. Поэтому как выглядел язык древних людей, живших 50-100 тысяч лет назад, ученые не 


\section{Психология и психотехника 12(99) • 2016}

могут и в ближайшее время не смогут узнать. Поэтому в настоящее время невозможно реконструировать происхождение древнейшего языка и вывести полные, и исчерпывающие доказательства гипотезы изначальной амбивалентности языка.

В настоящее время ученые более склоняются к гипотезе моногенеза, потому что она лучше согласуется с другими гипотезами. «Если человечество возникло в одной точке, то у него, вероятнее, всего был один язык. Но считать современные языки его потомками не совсем верно. Язык так сильно изменился, что от него ничего уже не осталось» ${ }^{[10]}$, - заявляет профессор Джеймс Пеннбейкер.

3. Фрейд в своей книге «Введение в психоанализ», ссылаясь на филолога Г. Шребера (Упсала), в принципе поддержал выдвинутое Г. Шребером в 1912 г. утверждение, что «сексуальные потребности принимали самое непосредственное участие в возникновении и дальнейшем развитии языка» [14, c. 185]. Начальные звуки речи служили сообщению и подзывали сексуального партнера, дальнейшее развитие корней слов сопровождало трудовые операции первобытного человека. Эти работы были совместными и проходили в сопровождении ритмически повторяемых языковых выражений. При этом сексуальный интерес переносился на работу. Одновременно первобытный человек делал труд приятным для себя, принимая его эквивалент и замену половой деятельности. Таким образом, произносимое при общей работе слово имело два значения, означая как половой акт, так и приравненную к нему трудовую деятельность. Со временем слово освободилось от сексуального значения и зафиксировалось на этой работе. Следующие поколения поступали точно так же с новым словом, которое имело сексуальное значение и применялось к новому виду труда. Теория утверждала, что «таким образом, возникало какое-то количество корней слов, которые были сексуального происхождения, а затем лишились своего сексуального значения» [14, с. 185].

В настоящее время данная теория не нашла своего подтверждения. Ф. Энгельс выдвинул другую теорию появления языка и речи из трудовой коллективной деятельности людей. Он объяснил это так: «У формирующихся людей зародилась потребность что-то сказать друг другу» и появилась эта потребность, потому что люди начали трудиться вместе, коллективно. Первобытные люди подчиняли свое поведение, свои действия общим интересам и можно утверждать, что язык, речь появилась из трудовой деятельности. Данная теория возникновения языка получила свое признание в обществе.
Общаться - это не значит, что-то сказать, в начале люди общались жестами, телодвижениями, грубыми звуками, но это уже был первый человеческий язык, выполнявший основную функцию общения. Позже возникла другая функция языка мыслительная, человек научился планировать свои поступки. Люди, развивая язык дальше, научились располагать слова одно за другим и понимать все взаимосвязи. Этой важной человеческой способностью не могут применять ни одно животное, которые могут только использовать один знак, а не несколько знаков последовательно. В человеческом языке возникали последовательности расположения слов: от простых к более сложным конструкциям, так появились синтаксические конструкции. Постепенно увеличивался словарный запас человека.

Теория возникновения языка филолога Г. Шребера не получила научного подтверждения, но эта гипотеза может быть полезной в объяснении многих сновидений человека, сохраняющих самые древние компоненты отношений, объясняет в них различные символы, истолковывая их с этой точки зрения сексуального характера поведения.

Также может объяснить, почему люди, ругающиеся матом, чаще других людей по исследованиям Дэвида Стиллуэлла из Кембриджского университета являются более честными, склонными говорить правду ${ }^{[12]}$. Возможно это происходит из-за того, что мат является более древним языком первобытных людей, на котором говорили для того чтобы выразить свои мысли, а не для того чтобы их скрыть. В первобытнообщинном строе не было столько условностей, таких изощренных законов, также этических, нравственных предрассудков в отношениях между людьми. Люди, говорящие сегодня матом, выражают сильные негативные и позитивные эмоции, они как бы соотносят себя с тем периодом, когда не нужно было столько врать, скрывая любые свои чувства, дерзкие, слова даже если они неприятны другой стороне. Возможно, данные люди, склонные ругаться матом, сохранили те первоначальные, базисные основы первобытного человека в своем подсознании и не полностью перевоплотились, трансформировались, переродились в современного человека. Возможно, не стоит отбрасывать теорию происхождения языка, выдвинутую Г. Шребером и упомянутую 3. Фрейдом в своей книге «Введение в психоанализ». Возникновение языка и речи это сложный многоуровневый процесс, который невозможно в современных условиях воссоздать, чтобы проверить все выводы, в выдвинутых гипотезах о происхождении языка. Возможно, зарождение языка происходило на разных уровнях 
и по разным направлениям, в том числе и с целью сексуального привлечения партнера.

\section{Противоположный смысл первоначальных слов или изначальная амбивалентность языка, слова}

В человеческом обществе существует амбивалентность чувств, эмоций, поведения, об этом подробно написал 3. Фрейд, но также в различных языках существует амбивалентность слова. Слово в древности могло иметь два противоположных значения, и только жест, какой-либо знак мог подтвердить то или иное значение данного слова, тем более слова «нет» в языках изначально не было. В английском языке «luck»- удача, шанс и «lack» отсутствие чеголибо, недостаток. Оба слова очень близки по написанию и произношению, отличаются одной буквой, но вмещают совершенно разный смысл. «Ken» в иероглифическом письме означает сильный и одновременно слабый и может быть понято только с изображением дополнительного знака в письме это сидящий человек, значит человек слабый и наоборот.

Ведь даже в современном китайском языке тоже есть амбивалентность слова, точнее иероглифа кризис и новые открывающиеся возможности изображаются одним иероглифом. Это подтверждает мысль, что противоположности в слове имеются во многих языках возможно, во всех языках мира. Лингвист К. Абель (1884) впервые обративший на эту закономерность назвал ее «противоположным смыслом первоначальных слов» ${ }^{[1,, .259]}$.

Здесь загадка амбивалентности чувств, исходящая, от самых древних времен, когда человек становился человеком и амбивалентность первых слов. В чем разгадка такой двойственности чувств и слов?

Возможно, рациональность человека сподвигла его экономно использовать иррациональность, когда чувства имеют амбивалентность, а одни и те же слова имеют противоположный смысл. С этой точки зрения можно рассмотреть многовалентность наших физических органов: рук, ног, носа, несущих не одну функцию, а множество функций.

В чем разгадка такой двойственности чувств и слов? В современную эпоху можно попытаться разгадать посредством трансцендентальности, понятия введенного И. Кантом. Знание получается путем опыта и исследований, но если невозможно получить знание таким путем, то можно использовать метод трансцендентальности, когда новое знание с опытом не связано. Понятие схоластической философии, обозначающее аспекты бытия, которые выходят за пределы ограниченного суще- ствования, эмпирического мира. Трансцендентальность характеризует высшие и универсальные предметы метафизического познания. Иммануил Кант придал термину гносеологическое значение. Понятие трансцендентальности в его философии характеризует множество априорных условий возможного опыта, формальных предпосылок познания, которые организуют научный опыт ${ }^{[13]}$.

Изначальная амбивалентность слова может помочь в расшифровке сновидения, не имеющего, как и древние языки, слова нет. Во сне, тем не менее, в связи с дополнительными деталями, все понятно и слова «да» или «нет» не нужны для понимания смысла сновидения.

Интересный пример амбивалентности слова можно привести из Facebook. На одной из страничек была опубликована еще одна амбивалентность, выраженная слоганом: «КНДР: важнейшие события 2016 года: “Увенчание 200-дневного ударного труда, сотворение чудес превращения беды в счастье"».

\section{Бессознательное - величайшее открытие XX века}

Эвристическое обнаружение бессознательного 3. Фрейдом по значимости для человечества ничуть ни меньше, чем открытие Н. Коперником вращения Земли вокруг Солнца, И. Ньютоном закона тяготения или А. Эйнштейном закона относительности, а не вручение Нобелевской премии при трехкратном выдвижении Зигмунда Фрейда служит подтверждением предвзятости Нобелевского комитета. В начале XX века, до этого считалось, что человек разумен, так утверждал Кант. Но почему многие дела, поступки человека были не логичны, не понятны и часто происходили во вред самому человеку? Бессознательное объяснило многое из того, что раньше скрывалось от умозрения человека и объяснило многие его поступки, и это великое открытие 3. Фрейда объяснило многие вполне материальные поступки человека, его потаенные мотивы, их причины, предопределило новые более близкие к реальности взгляды на человека.

Бессознательное в человеке составляет большую его часть и скрыто как от данного человека, которому оно принадлежит, так и от психоаналитика, желающего постичь его с целью помочь пациенту. Скрытое в большей части определяет мотивы человека, его поступки, устремления и достижения, неврозы и психозы. Поэтому для аналитического понимания индивида необходимо знать внутренние подсознательные процессы человека. 3. Фрейд доказал, что бессознательные процессы 


\section{Психология и психотехника 12(99) • 2016}

человека играют ведущую роль в мотивации и поступках человека. Большая часть нашей психической жизни происходит на уровне бессознательного, именно там закладываются основы мотивации человека, стимулы его поведения, это есть сфера психоанализа, родоначальником, которого является 3. Фрейд.

Триада в психоаналитической деятельности есть: терапевтический контакт, концептуальный проект и систематический самоанализ. Со временем психоаналитическая терапия развивается, появляются новые исследования, определяющие новые техники, открываются грани сознательных и бессознательных процессов.

По прошествии времени психоанализ установил обширные и глубокие связи с другими методами исследования: методами естественнонаучного наблюдения, соматического осмотра, психологического эксперимента, антропологических полевых исследований и исторических изысканий. Дополнить связи психоанализа может лексический анализ речи, текста, пронизывающий всю триаду психоаналитической деятельности, соединяющий все связанные многочисленными методами исследования и являющийся дополнением к этим методам исследований.

Аналитическая терапия исходит из определенных принципов и включает в себя: посещение психоаналитика пациентом, беседу между ними, где общение происходит в виде речи, слов. Поэтому разговор, точнее слово является важнейшим источником получения знаний о человеке. Аналитик также обращает внимание на все стороны поведения пациента, закрыл ли за собой он дверь, какая походка, жесты, с какими чувствами говорит пришедший на прием.

Но соотношение полученных сведений о нем из слов, из поведения является разным. Пациент должен много рассказывать о себе, чтобы объяснить все свои проблемы, недуги с которыми он пришел на прием, поэтому больше сведений о человеке аналитик получает из рассказа пациента о себе, что противоречит общепринятому правилу.

В «Субботних вестях» с Сергеем Брилевым один из интервьюеров сказал, что только 25\% знаний о человеке мы получаем вербальным путем. Остальные 75\% знаний о человеке мы получаем из невербальной составляющей.

В статье Н.И. Козлова «Невербальное общение» написано, что соотношение отличается как 10/90. Сегодня, 60\% в общении между людьми составляет невербальная часть, то, что люди передают друг другу телом, через позу, жесты и выражение лица. Еще $30 \%$ общения происходит через интонации и звучание голоса ${ }^{[8]}$. Таким образом, 90\% того, что люди выражают друг другу, не связано с речью, с вербальной составляющей.

Таким образом, область распространения лексического анализа должна быть 10-25\% от всей полученной информации о человеке. Это тоже достаточно, чтобы проводить аналитическую работу по речи, по слову, по ключевой фразе.

В нашей работе по лексическому анализу мы будем рассматривать слово в связи с эмоцией, с интонацией, с тем или иным чувством, с которым слово произносится. В психоаналитике важно эмоциональная окрашенность каждой фразы, каждого слова, даже междометия или предлога. Поэтому область лексического анализа речи человека расширяется. Анализ текста, напротив не предполагает услышать эмоцию каждого слова, но чувство всё равно передается посредством фразы.

Психоаналитик заглядывает в подсознательный процесс, пациент рассказывает личные, сексуальные проблемы и по этой причине психоаналитик больше должен ориентироваться на речь. Он извлекает больше информации для анализа из слова, из речи, из рассказа. Психоаналитик обязательно подмечает невербальное содержание пациента, но больше получает информации вербальным путем, через речь, слово. Эмоциональная наполненность слова, фразы служат важной составляющей в аналитической работе.

Пациент может, отвечая на вопрос, аналитика, рассказать свою историю, начиная даже не с рождения, а до своего рождения, как вынашивала его мама, как он воспитывался. Поэтому психоаналитик больше узнает из слова, из речи пациента. Психоаналитик обнаруживает бессознательные мотивы, анализирует сознательные и подсознательные процессы индивида, то есть он ищет смыслы, анализируя слова, проявления эмоций, жесты, походку.

В проводившемся опросе у психоаналитиков прозвучало, что больше они узнают на приеме из вербальной составляющей, то есть из речи, из рассказа самого пациента. Они могут и должны задавать вопросы и пациент должен отвечать, иначе ему не смогут помочь провести аналитическое лечение. Первый сеанс у психоаналитика может проходить вообще без вопросов, пациент часто говорит все шестьдесят минут и психоаналитик внимательно слушает говорящего и старается понять скрытый смысл, скрываемый за словами или даже не озвученный в силу сопротивления. Важной задачей аналитика является слушать нового человека, думать, что за человек, какова его судьба, думать об этом, но не перебивать, не спрашивать. 
Если начинать спрашивать, то психоаналитик превращается в юриста, в милиционера. Необходимо послушать человека бессознательно, не давая сознательному вторгаться в человеческую беседу.

Пример, рассказанный П.С. Гуревичем, на приеме у аналитика происходит следующий разговор с пришедшей женщиной.

- Часто плачете? - тихо спрашивает психоаналитик.

- Да, - отвечает она.

Психоаналитик сидит и думает, что за женщина перед ним находится. Он подключается к разговору и получается интервью. И это работа с бессознательным. Анализ подтекста запускает интуицию, весь жизненный опыт и это работа, по сути, с бессознательным. Сознание, которое всегда выскакивает в обычном разговоре вперед, нужно усмирять и нужно вести разговор с бессознательным ${ }^{[7]}$.

Психоаналитическая работа предполагает получение большей информации о человеке вербальным путем, через слово. В отличие от простого общения, где получаемое знание о человеке распределяется как 25/75 (то есть примерно двадцать пять процентов получаемых знаний о человеке получается из вербальных данных и семьдесят пять процентов знаний о человеке приходится на область невербальной информации), психоаналитик, напротив, большую часть информации для своего анализа получает из вербальной составляющей.

\section{Ключевые слова, характеризующие человека}

Термины «ключевое слово», «смысловые вехи» применяются для исследования текста и могут быть использованы для анализирования бессознательных процессов человека в психоанализе, проявленных в речи человека.

В связи с тем, что психоанализ выявил бессознательные процессы человека и доказал, что они играют ведущую роль в мотивации и поступках человека. Сознательное рационализирует подсознательные решения человека. Поэтому в речи должны прорываться слова из бессознательного в речь и слова прорываются такие, какие бы индивид не хотел бы говорить. Из слов как из кирпичиков строится здание речи, смыслов содержащиеся в бессознательном и сознательном мироустройстве человека. Если бессознательное составляет большую часть внутренних процессов человека, то слова из бессознательного должны прорываться посредством речи. Возможно, данные слова не взаимосвязаны с контекстом внешнего сознательного процесса и выхвачены из сути речи, лексической стилистики. Независимо от смысла всей фразы целиком, ключевые слова выявляют свой скрытый, даже от говорящего, бессознательный смысл. Данные слова могут иметь, по меньшей мере, два значения синонимичности непосредственно относящейся к цели высказываемого и с другой стороны к скрытой подсознательной проблематике, симптоматике индивидуума.

Для анализа бессознательного важны именно данные слова, слова из подсознания, не поддавшие самоцензуре и нечаянно высказанные. Они определяют истинные мысли и мотивацию человека.

В психолингвистике термину «ключевые слова» близок термин «смысловые вехи», которым обозначены единицы внутренней речи, соотносимые со словами текста. Данные термины использовали в Н.И. Жинкин и А.Н. Соколов для анализа различных текстов. Термин «ключевое слово» используется в разных науках, в литературоведении оно означает лейтмотив текста, в информатике ключевое слово - это слово или словосочетание, которые несут основную смысловую нагрузку с точки зрения информационного поиска. Процесс выделения ключевых слов в психолингвистике называется индексированием, суть его заключается в экспериментально-статистическом определении НКС (минимальный Набор Ключевых Слов) [2, с. 19].

Психоанализ, открыв бессознательное в человеке, определяющее в большей степени сущность человека, переосмысливает все накопленное человечеством научное достояние и должен найти, переосмыслить и использовать свой категориальный аппарат. Такими новыми терминами в психоанализе могут стать ключевые слова и смысловые вехи для еще более точного исследования бессознательного человека в речи, в тексте.

Ключевыми словами могут быть названы слова, выхваченные из контекста речи, определяющие скрытые мотивы поступков индивида, выявляющие истинную сущность человека, его подсознательную субстанцию, не соответствующую и противоречащую с внешней показной деятельностью.

Данные слова продолжают осмысление 3. Фрейда, названное оговоркой, опиской по Фрейду, когда человек проговаривает вдруг слова, содержащие смысл не тот, который хотел он высказать, порой даже противоположный тому, что человек говорит. Оговорка по Фрейду выявляет непосредственные мысли человека, истинные чувства, мотивы человека, сказавшего эти неправильные слова.

В процессе общения с пациентом психоаналитику необходимо воспринимать полный контекст коммуникации, обращаясь к средствам визуализа- 


\section{Психология и психотехника 12(99) • 2016}

ции, аудизации, кинестетики; одновременно сравнивать, анализировать всю поступающую к нему информацию через все органы чувств. Во время беседы нужно понять общий смысл сказанного человеком, за высказанным угадать скрытое, что из-за сопротивления не сказал пришедший на прием, и в третьих, нужно замечать, выхватывать отдельные ключевые слова, сказанные собеседником. Он может высказать данные слова осознанно и бессознательно, но они являются важными для понимания мотива, источника какого-либо явления у человека, симптома или невроза.

К примеру, к психоаналитику приходит семейная пара. Женщина усаживается прямо напротив аналитика, муж несколько дальше на диване за женой. Женщина говорит весь прием, муж сидит, отрешившись от разговора, и ничего не говорит. Она жалуется, что нет интимной близости в семье, что они находятся на грани развода. В чем причина разлада в семье? Что в семье происходит? Но в речи женщины звучат фразы, выявляющие ее пристрастие к алкоголю, она в частности говорит, рассказывая о своих семейных отношениях, что она может пить, может не пить. Эти фразы типичные для человека пристрастного к алкоголю. Непьющий обычно эти фразы не употребляет. Дальше ситуация подтверждается, когда в конце приема психоаналитик говорит даме, что в первую очередь для сохранения семьи вы должны бросить пить. Она в волнении говорит, что нет, она не пьет, ну столечко, мало, что подтверждает - она выпивает, так обычно говорят пристрастные к алкоголю люди. Эти слова являются одними из ключевых фраз во всей беседе, и они правильно определяют причину симптомов распада семейной жизни.

Для завуалирования, сокрытия цели своих поступков, утаивания истинного смысла своих слов человек может попытаться сообщить так называемые слова, которые определяются как ловушки для этого самого высказывания данного человека. Если человек говорит, я не с такой целью это делаю или я этого не делал, то часто это означает, по меньшей мере, что человек об этом размышлял. Если человек сразу заявляет, что я этого не делал, то чаще всего именно он это сделал или намеревался совершить. Особенно, когда человек сразу при первом намеке сразу отвечает, что я этого не делал. К примеру, преступник при поимке часто говорит, что он не совершал этого преступления. Это подсказка для следователя, что сделал именно это преступление данный человек.

Слово и поступок человека тоже могут быть проанализированы. Думаю это взаимосвязано в первую очередь. Но каким образом может быть слово, произнесенное человеком взаимосвязано с его поступком, характером это большой вопрос для исследования.

\section{Восприятие отрицания в психоанализе}

В психоаналитической работе аналитик должен в своем словотворчестве ориентироваться на положительный смысл своих формулировок, пожеланий, демонстрировать перспективы пациенту. В своей деятельности нужно избегать употребления частицы «не». Она не должна фигурировать в разговоре с клиентом ни в запросе, ни в работе, необходимо ставить задачи в позитивном ключе. Если команда исходит в негативном ключе, то человеческий мозг воспринимает данную команду неоднозначно. Если мы критикуем какие-либо поступки клиента, то это является малодейственным для переосмысления и не совершения данных поступков критикуемым. Психоаналитику необходимо формулировать свои пожелания в положительном ключе для того, чтобы активизировать ментальные ресурсы человека. Нужно говорить не «не хочу быть одинокой». Психика человека не помогает в этом случае решить данную задачу. В таком определении задачи ментальность человека не помогает добиться данной цели, но если задача поставлена в позитивном ключе, то задействует подсознательные ресурсы человека. Поэтому лучше говорить: «Я хочу быть общительной, иметь много настоящих друзей».

В соционике утверждают, что отрицание с частицей «не» плохо воспринимается, но слово, стоящее за отрицанием, за частицей «не» акцентируется и отчетливо, ярко высвечивается психикой человека. Допустим, кто-то говорит «не думайте о зеленой обезьяне», но этот запрет действует наоборот, обезьяна названа, она представляется, о ней человек начинает размышлять, визуализировать, то есть происходит с точностью до наоборот.

В видеорекламе Airbnb «Приезжай пожить» использованы слова с частицей «не», которые акцентируют и заостряют особенное внимание на следующем за ним слове для того чтобы привлечь внимание потенциального покупателя. Реклама в YouTube звучит следующим образом: «Не приезжай в Париж, не приезжай в Лос-Анджелес, не приезжай в Токио. Приезжай пожить, ты будешь как дома в любой точке мира, снимая жилье через Airbnb. Чувствуй это даже во сне. Пробуй местную кухню, стань своим, куда бы ты ни направился, не просто приезжай туда. Приезжай пожить, даже всего на одну ночь».

По частице «не», которая не воспринимается яркий пример в песне Ника Кэйва «Death is not 
the End» (Смерть не конец). Частица «не» «not» акцентирует второе слово «the death» (смерть), но частица не воспринимается бессознательно как отрицающая, то есть эмоциональный смысл высказывания «The death is not the end» (Смерть не конец), положительный, а не отрицающий. А следующая фраза звучит «Нарpy end» (Счастливый конец), которая относится к положительному подсознательному смыслу первой фразы. И смысл всей фразы становится означающей, что смерть - это счастливый конец. По-моему, Nick Cave исполнитель, зная это, программирует слушателя.

Слово, имеющее негативную аннотацию, не усваивается, не воспринимается как слово, отрицающее смысл отрицания. Это особенно заметно, когда мы нацеливаем наши знания на встречный эффект, вроде сказано один раз, второй раз, третий раз, а все-равно слово не доходит, тайна бессознательного, которая до сегодняшнего времени не получила полного теоретического и практического обоснования. К примеру, профессор много раз на занятиях говорил о том, что не следует уходить от специальности, не следует вторгаться в другие сферы знания. Студентами это не усваивается, хотя звучит.

Также в психоаналитической работе нужно избегать таких негативных высказываний, как, например, тупица, глупый, чтобы не запрограммировать порицаемого на такую модель поведения, что он всегда будет думать о себе, что он тупица, глупец.

Психоаналитик, прежде всего, должен видеть в человеке возможности и выстраивать цели и задачи для человека и образ каким должен тот быть. Даже критикуя, он должен стараться частицу «не» не употреблять, а поведенческую ситуацию описывать как позитивную, стараться опираться на положительный образ, но в пределах того, насколько это возможно.

\section{Несамостоятельные слова как предвестие бессознательного}

Слово - это материал, из которого сложена наша речь, текст. Как из атомов создано мироздание, так из слов сложен текст, наша речь. Но если в психических процессах человека большая часть составляет бессознательное, то какие слова могут быть определены напрямую как бессознательные и могут ли быть слова бессознательными? Слова в языке раскладываются на «самостоятельные» и «несамостоятельные». Самостоятельные слова это глаголя, существительные, прилагательные и большинство наречий, передающих основную информацию и выражающих идею. И второй ряд слов в этой классификации несамостоятельные помогают формулировать, индивидуализировать, упрощать речь. Они по-другому воздействуют на ментальную сущность человека. Они могут определить личные качества, характер человека, эмоциональное состояние социальное положение, степень уверенности в сказанном. Такими словами обычно являются местоимения, союзы, в английском языке артикли. В английском языке таких слов около пятьсот, в русском языке примерно столько же.

В исследовании Джеймса Пеннбейкера текстов поэтов, писателей, покончивших с собой и тех, кто умер естественной смертью, он обнаружил, что самоубийцы не используют больше негативно окрашенных слов. Различие оказалось в другом в частоте употребления таких слов как «я». Местоимения показывают, что для человека является наиболее важным, на чем он более всего сосредоточен. Профессор Джеймс Пеннбейкер утверждает: «Уловить, что-то на слух практически невозможно, поэтому мы анализируем стенограммы - и только с помощью специальных компьютерных программ. Но представим себе человека в подавленном состоянии. Из всех сказанных им слов 6,5\% придется на местоимение «я» - против $4 \%$ у людей в спокойном состоянии» ${ }^{[10]}$. Допустим человек вместо «На улице светит солнце», говорит «Мне кажется, что на улице идет дождь». Люди, которые чувствуют себя, подавлено чаще «якают», чем уверенные в себе люди. Также человек может говорить о себе в третьем лице, персонифицировать себя с третьим лицом, что может послужить симптомом невроза.

Если человек лжет, то вместо фразы «Я не брал эту книгу», скорее всего, скажет: «Человек честный такого не сделает». В речи лгунов чаще звучат такие слова, как, «но», «однако», «никакой», «никогда». При анализе судебных протоколов обвиненных, совершивших преступления, но не сознающихся сразу, такая взаимосвязь прослеживается. В бизнесс-среде по употреблению несамостоятельных слов можно определить отношения в коллективе, лидера или главного по должности. Лидер чаще говорит уверенно без предложений с двойным смыслом. Также по применению слова «мы» или «они» о своих коллегах может позволить понять о взаимоотношениях данного человека с коллегами. Поэтому очень важно обращать внимание в психоаналитической работе на частотность употребления несамостоятельных слов, которые могут показать личные внутренние качества человека. 


\section{Психология и психотехника 12(99) • 2016}

\section{Модель ключевого слова}

Подсознательные процессы человека, составляющие неотъемлемую большую часть его психики, относятся к трем регистрам по Жаку Лакану: воображаемое - символическое - реальное. Эту Схему трёх степеней бессознательного он применял к бессознательному: первый этап, доструктуралистский был посвящён «воображаемому», второй этап, структуралистский, - «символическому», третий этап, постструктуралистский, - «реальному»; в некотором отношении это соответствовало триаде Фрейда «Я» - «Сверх-Я» - «Оно».

«"Мир есть мое представление": вот истина, которая имеет силу для каждого живого и познающего существа, хотя только человек может возводить ее до рефлективно-абстрактного сознания; и если он действительно это делает, то у него зарождается философский взгляд на вещи», - написал А. Шопенгауэр ${ }^{[15]}$. Поэтому человеку свойственна субъективность восприятия и отражения реальности. Действительность настолько разнообразна, многопланова, что отражая, описывая реальность, каждый человек будет воспроизводить ее по-своему.

Художественный мир произведения субъективен, каждый автор выстраивает свою, ему близкую абстрактную реальность и создает свою модель отображаемого мироздания. Под моделью мира обычно понимается, как написал В. Белянинов: «... сумма знаний об окружающей субъекта среде и его

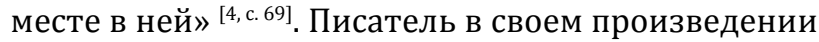
производит свое понимание среды обитания и его места в ней и создает свою модель мира в своем произведении в контексте эмоционально-смысловой доминанты. «Слово доминанта в психологии обозначает временно господствующую рефлекторную систему, которая обуславливает работу нервных центров организма в конкретный временной промежуток времени и поэтому придает деятель-

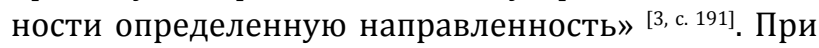
анализе речевой деятельности человека речь может идти о доминанте физиологического и психологического, в том числе поведенческого характера человека. В конечном счете, представить модель художественного произведения автора и модель речевого высказывания человека можно опираясь на доминанты в их содержании. Невозможно спрессовывая всю полученную информацию в меньший объем, не потерять многие взаимосвязи, мысли, но оставшиеся доминанты произведения или речи человека могут правильно отражать суть произведения или речь человека.

К примеру, другое определение модели из академического словаря, - «модель в широком пони- мании есть образ, условный или мысленный - изображение, описание, схема, чертёж, график, план, карта и тому подобное или прообраз, образец какого-либо объекта или системы объектов, используемый при определённых условиях в качестве их «заместителя» или «представителя» ${ }^{[9]}$. Данное определение близко к нашему пониманию образа художественного произведения как модели ключевого слова.

Каждое цельное художественное произведение может быть выражено своеобразной моделью в нескольких предложениях. Многие писатели не согласны с этим выводом, среди них был Л.Н. Толстой, сказавший, что ответом на вопрос о чем данное произведение единственный: «Я сказал, что сказал». Но Ф.И. Достоевский о своем произведении «Преступление и наказание» сказал: «Молодой человек, живущий в крайней бедности, по легкомыслию, шаткости в понятиях, поддавшись некоторым странным, «недоконченным» идеям, ... решился... убить одну старуху, дающую деньги на проценты... Неожиданные вопросы встают перед ним. И он кончает тем, принужден сам на себя донести...».

Безусловно, интерпретаций текста может быть столько же много сколько читателей. Главный вопрос насколько адекватной будет интерпретация и сможет ли она реконструировать истинный смысл текста. Всякая модель художественного произведения является неполной, неточной по отношению к оригинальному произведению. Даже если произведение является цельным, модель в силу своей краткости сокращает многие второстепенные смыслы, понятия, подтекст и является неполным. Художественные произведения обладают образностью, многозначностью, также данными качествами обладают модели данных произведений. В отличие от математических моделей каждое слово образует много лексем, парадигм, а сочетания нескольких слов добавляет новые смыслы и образует бесконечное количество различных смыслов. Но всё равно модель в силу своей краткости меньше оригинала, но бесконечна по смысловым значениям, заключенным в ней. Слово как модель имеет право на существование и поэтому авторы художественных произведений называют свое творение кратко и обычно одним или двумя словами. Слово, часто заложенное в названии произведения в самом произведении, как древо расходится разными ветвями с разными смыслами, различными образами. Слово, лексема является корневой системой произведения, из которого произрастает все произведение и слово по своей сущности и образной составляющей смыслов является бесконечным в 
своих расширяющихся значениях. В отличии от математической однозначной модели слово изначально многозначно.

Если модель художественного произведения сводится к одному высказыванию, не может ли она сводиться к одному ключевому слову, раскрывающему, раскручивающему весь смысл произведения. Допустим, произведение Ф.И. Достоевского «Преступление и наказание» в виду, того что там не показано тюремное наказание, мучения Ф. Раскольникова в полицейском изоляторе, суда над ним можно представить одним словом преступление. Величайшее произведение Л.Н. Толстого «Война и мир» в четырех томах, можно представить дихотомией двух ключевых слов, - война-мир и затем раскручивая дихотомию двух слов можно произвести цельное многотомное произведение.

Разве не об этом говорится в главной книге христианской религии «Библии»: «Сначала было слово и слово было от Бога и слово было Бог» и затем во всех текстах книги развивается основная мысль, прозвучавшая вначале. Сема Бог, значение и суть контекста Бог, Божественного распространяется по разным производным историям, сюжетам разных авторов данной книги и пронизывает все тексты Библии. Как спираль гена свернутая, разворачиваясь, она производит разные смыслы, разные значения, но подчиняется главной теме Бог и ключевому слову Бог во всем и во всех книгах, то есть библиях, что в переводе означает книги.

Рассказ, речь, фраза собеседника может сводиться к одной модели и в конечном итоге к одному ключевому слову. Одно слово или ключевое слово в содержании речи человека включает в себя модель жизненного мироздания данного человека.

Современное модное понятие квантовости, клиповости сознания может быть приведено к единому понятию в правильно подобранной модели. Более того такая модель уже существует и отражена в одном ключевом слове и это слово есть квантовость сознания. Возможно, такая модель будет не цельной, но она будет отражать и включать в себя все смыслы клиповости начального содержания и передавать основную идею. Следовательно, такую модель можно будет представить одним ключевым словом, которое будет возвышаться на вершине пирамиды различных смыслов постмодернистского художественного произведения или устного рассказа человека. Данное ключевое слово характеризует человека, писателя во всех аспектах, вмещает множество смыслов. Образ данного слова, развитие понятия, вмещает весь смысл сказанного или написанного и по сути является бесконечной как само слово.
Реверсивная связь, движение от слова к образу к развертыванию смыслов, заключенных в слове является сложной задачей и имеет свою предельность, ограниченность. Такое реверсивное движение возможно, но требует огромных знаний, богатейшего опыта аналитика, разгадывающего значения модели одного слова или расшифровывающего значения модели художественного произведения, рассказа, высказывания человека. Реверсивный процесс распознавания смыслов слова требует огромных знаний, навыков, больших умственных усилий, опыта во всех областях деятельности. Это работа сопоставима с герменевтикой от греческого hermeneuo - разъясняю. Это искусство понимания, как постижения смыслов, так и значения знаков; 2) теория и общие правила интерпретации текстов; 3) философское учение об онтологии понимания и эпистемологии интерпретации. В словаре академическом написано, что «герменевтика возникла и развивалась в конкретных формах в толковании сакральных, исторических или художественных текстов» ${ }^{6]}$. Причем время в искусстве понимания играет важную роль в герменевтике, произведение искусства имеет бесконечные смыслы, что в разные времена произведение искусства, определенные моменты в произведении прочитывается с разными значениями и смыслами, может открываться различный контекст в одном и том же произведении. В разное время акцент делается на различные моменты и таким способом обнаруживаются важными различные идеи, смыслы в одном и том же произведении.

Модель ключевого слова может быть использована в самых неожиданных вариантах, таких как ключевое слово, в произведении искусства, какого-либо кусочка текста или речи, но также модель, собирающая все смыслы, может применяняться ко всем характеристикам человеческих качеств. К примеру, в настоящее время научно-обоснована модная модель OCEAN, используя которую якобы выиграл президентские выборы Д. Трамп. В английском языке существует, по мнению ученых около 18000 слов, характеризующих поведение, характер человека, нравы. Из 18000 можно вывести пять слов, включающих смыслы всех 18000. Это тоже своеобразная модель ключевых слов на вершинах пирамид, которых располагаются пять слов, включающие все смыслы человеческих качеств.

\section{Ключевые слова, характеризующие время. Слово Post-truth 2016}

Важная задача поиска сущности человека по ключевым словам, извлеченным из всего контекста 


\section{Психология и психотехника 12(99) • 2016}

сказанного, написанного и соединенного со всем поведением человека, его характером, жестами, поступками содержит большую потенциальную возможность для аналитической работы и понимания человека. Конвергенция разнообразия смыслов и индукция, освобождение, очищение от второстепенных значений для обнаружения смысла есть важная аналитическая работа. В конечном базисе остается несколько идей, которые воплощаются в идеальном варианте в одну идею, в одно слово. С одной или несколькими субстанциями можно производить исследование и анализ.

Механизм исследования по ключевому слову дает возможность выводить ключевое слово эпохи, года, дня. В наше время стало распространенным словом «как бы», его можно услышать повсюду на улице, на работе, при приеме на работу, в магазине. Допустим, продавец шаров, наполненных азотом для одурманивания сознания, при вопросе о вдыхании такого газа, не приведет ли это к летальному исходу, отвечает «не вроде как бы нет». Что он хотел сказать такой многосложной фразой? Это есть бессознательная фраза об опасности данного занятия. Но это слово гораздо глубже отображает нашу эпоху, чем приведенный смысл в данном высказывании, в наше время распада качеств человека распадаются многие устойчивые понятия, рыцарь, буржуазия, история, это уже современная дисциплина. Человек становится во многом не уверен, потому что размываются привычные границы, и в нашу речь ворвалось слово «как бы». На вопрос: «Вы работаете?», появляется ответ: «Как бы работаю». Нет такой работы, которая бы воспринималась как на самом деле. На вопрос: «Вы замужем?», ответ: «Как бы». Не пришло бы сельской женщине сказать, что она «как бы замужем». Это не просто слово-паразит, чтобы заполнить пустоту, хотя и относится к таким словам. «Как бы» - слово неуверенного в своей правоте человека это, скорее всего обмолвка, выявляющая чувство неуверенности. Все закружилось и пришло в движение, появились эксцентричные браки, поменялись гендерным роли в семье. Муж остается дома ухаживать за детьми, а жена идет на работу, зарабатывать на всю семью.

\section{Ключевое слово, характеризующее время. Post-truth (послеправда)}

Оксфордский словарь, выявляя каждый год, слово года, определил слово 2016 - это «постправда» ${ }^{[19]}$. Данное прилагательное в английском языке, в русском языке это существительное обозначает новую суть времени, при которой объективные фак- ты играют менее весомую роль в формировании общественного мнения, чем апелляции к эмоциям и личным убеждениям.

Представители издания пояснили, что явление, которое называет слово «постправда», вошло в нашу жизнь достаточно давно, однако этот термин стал активно использоваться носителями языка после заявления о выходе Соединенного Королевства из Евросоюза, а также выборов президента в США, на которых неожиданно победил миллиардер Дональд Трамп. В этот период слово стало общеупотребимым и появилось в речах многих политиков и газетных статьях. То есть слово постправда стало ключевым словом в западном мире в этом году и характеризует, вбирает в себя все смыслы данного года.

Отметим, что в шорт-лист Оксфордского словаря вошли такие слова, как «коулрофобия» (coulrophobia, боязнь клоунов), «брекзитер» (brexiteer, сторонник выхода Великобритании из ЕС) и «чатбот» (chatbot, программа, в которой пользователь говорит с компьютером, симулирующим разговор) ${ }^{[18]}$.

«Платон мне друг, но истины не надо» популярная для нашего времени поговорка. Truth можно перевести на русский как «правда» или как «истина». Английский язык не фиксирует тонкого различия между этими понятиями, существующими в русском языке. Вслушайтесь, как по-разному звучит: «Я говорю правду» и «Я говорю истину» - а по-английски в обоих случаях будет «I tell the truth». В русском языке существует различие - истина одна на всех, а правда у каждого своя. Истина объективна, а правда субъективна.

Определение post-truth, данное составителями словаря, подразумевает объективный характер truth, поэтому в качестве русской кальки будем использовать слово «постистина» и производные.

Оксфордские энциклопедисты объясняют: слово post-truth существует в английском языке уже десять лет, но в 2016 г. отмечен взрывообразный рост его популярности. В данном случае приставка «пост» подразумевает, что то или иное понятие, прежде бывшее очень важным, потеряло свою значимость. По-моему, важным для создателей «постистины» было слово «пострасовый», появившееся в американском английском в 1970-е гг., во время движения против расовой дискриминации как наступление новой эры, когда цвет кожи не является главной характеристикой человека. Следовательно, «эпоха постистины» - это время, когда истина потеряла ценность для социального человека.

Термин «политика постистины» (post-truth politics) использовали журналисты английских изданий, писавшие о референдуме, о выходе Велико- 
британии из Евросоюза и о президентских выборах в США. Понимание состоит в том, что сторонники Brexit, а также последователи Дональда Трампа, не интересуются истинным положением дел в стране, им нет дела до достоверно установленных и проверяемых фактов - им важны их собственные ощущения. Большая часть британцев убеждена, что еврочиновники норовят зарегулировать всю их жизнь и отобрать у них последние заработанные деньги, Всякое объяснение истинного, по мнению сторонников Евросоюза, положения дел, это не производит никакого воздействия. Сторонники Трампа Д. уверены, что Барак Обама повысил налоги и чуть не лишил их права на ношение оружия, - и сколько ни объясняй с фактами, что это не так, они упорно отказываются пересмотреть свое мнение. Трамп Д. в прошлую компанию набрал популярность, потому что публично поставил под сомнение факт рождения Обамы на территории США. Это было опровергнуто много раз, но это, удивительным образом, не изменило доверия значительной части электората к Трампу.

Пренебрежение фактами в современном мире и отказ от осмысления правдивой информации характерны сегодня для любых категории населения, распределенным по различным группам, будь это противники ГМО, поборники «органических продуктов», «антипривочники» или сторонники той или иной политической партии. Объяснить все эти многочисленные факты искажения реальности может аналитическая работа, использующая великие открытия 3. Фрейда и его последователей в психоаналитической деятельности.

\section{Заключение}

Величайшее открытие Зигмундом Фрейдом бессознательного в психике человеке стало основой для появления нового направления - психоанализа. Большая часть нашей психической жизни происходит на уровне бессознательного, именно там закладываются основы мотивации человека, стимулы его поведения, это и есть сфера психоаналитической работы. Но самое удивительное: психоанализ раскрывает тайну человеческого поведения, его мотивацию, поступки, предопределяет его будущие действия. Психоаналитик может составлять развернутую картину внутреннего мира человека. С помощью нового направления, открытого 3. Фрейдом в начале XX века, может проводиться аналитическая терапия, человек может избавляться от многочисленных симптомов и неврозов.

В СССР психоанализ не изучался и даже был под запретом, как буржуазное учение. В России с 1990 г. начали появляться книги по психоанализу и начала проводиться психоаналитическая деятельность. Данная работа посвящена одной из сторон лексическому анализу текста, речи для выявления бессознательного по ключевым бессознательным словам. Приведен ряд теорий из разных научных направлений, которые могут быть использованы в психоанализе.

\section{Список литературы:}

1. Аннушкин В.И. Язык - речь - слово в духовной литературе // Wiki2. URL: https://wiki2.org/ru/Слово (дата обращения: 26.01.2017).

2. Бабенко Л.Г., Казарин Ю.В. Лингвистический анализ художественного текста. М.: Флинта: Наука, 2005.496 с.

3. Белянин В. Основы психолигвистической диагностики. Модели мира в литературе. М.: Тривола, 2000.248 с.

4. Белянинов В. Модели. М., 1997. С. 69.

5. Виноградов В.В. Словарь языка Пушкина: в 4 т. / Отв. ред. акад. АН СССР В.В. Виноградов. 2-е изд., доп. М.: Азбуковник, 2000.

6. Герменевтика это // Философская энциклопедия. URL: http://dic.academic.ru/dic.nsf/enc_philosophy/253/ГEPMEНЕВТИКА (дата обращения: 12.02.2017).

7. Гуревич П.С. Практическая психология для всех: Клинический психоанализ. М.: Канон+ РООИ «Реабилитация», 2017. 448 с.

8. Козлов Н.И. Невербальное общение // Психоголос. URL http://www.psychologos.ru/articles/view/neverbalnoe_ obschenie (дата обращения: 14.03.2017).

9. Модель// Советская энциклопедия. URL: http://dic.academic.ru/dic.nsf/bse/166420/Модель (дата обращения: 28.03.2017).

10. Пенбейкер Д. Говорящие слова // Harvard Business Review. 2012. Mart. C. 26.

11. Словарный запас. Что это? // Академик: словари и энциклопедии. URL: http://dic.academic.ru/dic.nsf/ruwiki/1334145 (дата обращения: 28.05.2017).

12. Стиллуэлл Д. Ученые: сквернословие связано с повышенной честностью. URL: https://news.rambler.ru/ science/35841471/?utm_content=news\&utm_medium=read_more\&utm_source=copylink (дата обращения: 16.02.2017).

13. Трансцендентальность это // Академик: словари и энциклопедии. URL: http://dic.academic.ru/dic.nsf/relig/777 (дата обращения: 25.03.2017).

14. Фрейд 3. Введение в психоанализ / Пер. с нем. Г. Барышниковой. СПб.: Лениздат, 2014. 543 с.

15. Шопенгауэр А. Первое размышление: представление, подчиненное закону: объект опыта и науки. Книга первая. О мире как представлении. Мир как воля и представление. URL: http://sv-scena.ru/Buki/Mir-kak-volya-ipryedstavlyeniye.5.html (дата обращения: 12.05.2017). 


\section{Психология и психотехника 12(99) • 2016}

16. Энциклопедический словарь юного филолога. М.: Педагогика, 1984. 352 с.

17. Юшкова Н. Словарный запас Пушкина // Стихи.py URL: http://www.stihi.ru/2010/03/24/1825 (дата обращения: 03.01.2017).

18. Post-truth: Оксфордский словарь назвал слово 2016 года // Мир24. URL: http://mir24.tv/news/world/15323840 (дата обращения: 02.04.2017).

19. Word of the Year 2016 is... // English Oxford living dictionaries. URL: https://en.oxforddictionaries.com/word-of-the-year/ word-of-the-year-2016 (дата обращения 23.03.2017).

\section{References (transliterated):}

1. Annushkin V.I. Yazyk - rech' - slovo v dukhovnoi literature // Wiki2. URL: https://wiki2.org/ru/Slovo (data obrashcheniya: 26.01.2017).

2. Babenko L.G., Kazarin Yu.V. Lingvisticheskii analiz khudozhestvennogo teksta. M.: Flinta: Nauka, 2005. $496 \mathrm{s.}$

3. Belyanin V. Osnovy psikholigvisticheskoi diagnostiki. Modeli mira v literature. M.: Trivola, 2000. $248 \mathrm{~s}$.

4. Belyaninov V. Modeli. M., 1997. S. 69.

5. Vinogradov V.V. Slovar' yazyka Pushkina: v 4 t. / Otv. red. akad. AN SSSR V.V. Vinogradov. 2-e izd., dop. M.: Azbukovnik, 2000.

6. Germenevtika eto//Filosofskaya entsiklopediya.URL:http://dic.academic.ru/dic.nsf/enc_philosophy/253/GERMENEVTIKA (data obrashcheniya: 12.02.2017).

7. Gurevich P.S. Prakticheskaya psikhologiya dlya vsekh: Klinicheskii psikhoanaliz. M.: Kanon+ R00I «Reabilitatsiya», 2017. $448 \mathrm{~s}$.

8. Kozlov N.I. Neverbal'noe obshchenie // Psikhogolos. URL http://www.psychologos.ru/articles/view/neverbalnoe_obschenie (data obrashcheniya: 14.03.2017).

9. Model' // Sovetskaya entsiklopediya. URL: http://dic.academic.ru/dic.nsf/bse/166420/Model' (data obrashcheniya: 28.03.2017).

10. Penbeiker D. Govoryashchie slova // Harvard Business Review. 2012. Mart. S. 26.

11. Slovarnyi zapas. Chto eto? // Akademik: slovari i entsiklopedii. URL: http://dic.academic.ru/dic.nsf/ruwiki/1334145 (data obrashcheniya: 28.05.2017).

12. Stilluell D. Uchenye: skvernoslovie svyazano s povyshennoi chestnost'yu. URL: https://news.rambler.ru/ science/35841471/?utm_content=news\&utm_medium=read_more\&utm_source=copylink （data obrashcheniya: 16.02.2017).

13. Transtsendental'nost' eto // Akademik: slovari i entsiklopedii. URL: http://dic.academic.ru/dic.nsf/relig/777 (data obrashcheniya: 25.03.2017).

14. Freid Z. Vvedenie v psikhoanaliz / Per. s nem. G. Baryshnikovoi. SPb.: Lenizdat, 2014. 543 s.

15. Shopengauer A. Pervoe razmyshlenie: predstavlenie, podchinennoe zakonu: ob"ekt opyta i nauki. Kniga pervaya. 0 mire kak predstavlenii. Mir kak volya i predstavlenie. URL: http://sv-scena.ru/Buki/Mir-kak-volya-i-pryedstavlyeniye.5.html (data obrashcheniya: 12.05.2017).

16. Entsiklopedicheskii slovar' yunogo filologa. M.: Pedagogika, 1984. 352 s.

17. Yushkova N. Slovarnyi zapas Pushkina // Stikhi.ru URL: http://www.stihi.ru/2010/03/24/1825 (data obrashcheniya: 03.01.2017).

18. Post-truth: Oksfordskii slovar' nazval slovo 2016 goda // Mir24. URL: http://mir24.tv/news/world/15323840 (data obrashcheniya: 02.04.2017).

19. Word of the Year 2016 is... // English Oxford living dictionaries. URL: https://en.oxforddictionaries.com/word-of-the-year/ word-of-the-year-2016 (data obrashcheniya 23.03.2017). 